\title{
Review:
}

\section{Microbial fuel cells for energy production from wastewaters: the way toward practical application}

\author{
Wei-feng LIU, Shao-an CHENG ${ }^{\dagger+}$ \\ (State Key Laboratory of Clean Energy, Department of Energy Engineering, Zhejiang University, Hangzhou 310027, China) \\ †E-mail: shaoancheng@zju.edu.cn \\ Received Sept. 17, 2014; Revision accepted Oct. 19, 2014; Crosschecked Oct. 24, 2014
}

\begin{abstract}
Much energy is stored in wastewaters. How to efficiently capture this energy is of great significance for meeting the world's energy needs, reducing wastewater handling costs and increasing the sustainability of wastewater treatment. The microbial fuel cell (MFC) is a recently developed biotechnology for electrical energy recovery from the organic pollutants in wastewaters. MFCs hold great promise for sustainable wastewater treatment. However, at present there is still much research needed before the MFC technique can be practically applied in the real world. In this review, we analyze the opportunities and key challenges for MFCs to achieve sustainability in wastewater treatment. We especially discuss the problems and challenges for scaling up the MFC systems; this is the most critical issue for realizing the practical implementation of this technique. In order to achieve sustainability, MFCs may also be combined with other techniques to yield high effluent quality or to recover more commercial value (i.e., by producing energy-rich or high value chemicals) from wastewaters. However, research in this area is still on-going and many problems need to be settled before real-world application. Advances are required in respect of efficiency, economic feasibility, system stability, and reliability.
\end{abstract}

Key words: Microbial fuel cell (MFC), Wastewater treatment, Sustainability, Scale up, Chemical production doi:10.1631/jzus.A1400277 Document code: A CLC number: TM911.45

\section{Introduction}

Sustainable treatment and utilization of wastewater are receiving intensive attention due to the growing shortage of freshwater resources, depletion of fossil fuel, and environmental pollution. At present, most traditional wastewater treatment processes consume energy and cause environmental problems ( $\mathrm{Li}$ et al., 2014). For instance, treatment of organic-rich wastewater consumes about $3 \%\left(1.5 \times 10^{10} \mathrm{~W}\right)$ of all electrical power produced in the USA each year

\footnotetext{
${ }^{\ddagger}$ Corresponding author

* Project supported by the National Natural Science Foundation of China (Nos. 51278448 and 51478414), the National High-Tech R\&D Program of China (863 Program) (Nos. 2011AA060907 and 2012AA051502), and the Specialized Research Fund for the Doctoral Program of Higher Education (No. 20110101110018), China

(C) Zhejiang University and Springer-Verlag Berlin Heidelberg 2014
}

(McCarty et al., 2011). Considerable amounts of greenhouse gases, such as nitrous oxide, carbon dioxide, and other volatile substances are released into the atmosphere. Furthermore, large quantities of excess sludge are produced during the treatment, disposal of which is energy and economically costly (McCarty et al., 2011).

However, wastewaters are actually a huge "energy storage tank". It is estimated that municipal wastewater contains approximately 9.3 times more energy than is currently needed for its treatment in a modern municipal wastewater treatment plant (WWTP) (Heidrich et al., 2011). So, how to efficiently capture the huge energy potential in wastewaters is of great significance for meeting the world's energy needs, reducing wastewater handling costs and increasing the sustainability of its treatment. To this end, various energy-efficient and resourcerecovering technologies have been developed. 
Typical examples include the anaerobic digestion (Liu et al., 2008) and dark fermentation (Li and Fang, 2007) processes. Recently, microbial fuel cells (MFCs) have emerged as a promising technology for wastewater treatment while recovering electrical energy from organic pollutants (Logan, 2009; Dewan et al., 2010; Cheng et al., 2014a). MFCs use microorganisms as the catalysts for directly converting the chemical energy available in the biomass into electricity. Only those microorganisms capable of transferring electrons outside the cell to insoluble electron acceptors (such as iron and other metal oxides, or to solid electrodes), called "exoelectrogens", contribute to electricity generation in MFCs (Logan, 2009). Currently, the most studied exoelectrogens belong to the $\alpha-, \beta-, \gamma-$, and $\delta$-proteobacteria (e.g., Geobacter sulfurreducens, Geobacter metallireducens, Shewanella oneidensis, Escherichia coli, Rhodopseudomonaspalustris) (Bond and Lovley, 2003; Min et al., 2005a; Ringeisen et al., 2006; Qiao et al., 2008; Xing et al., 2008); while some nonproteobacteria (e.g., Geothrixfermentans (Bond and Lovley, 2005)) and yeasts (e.g., Saccharomyces cerevisiae (Walker and Walker, 2006)) are also capable of exocellular electron transfer. A typical MFC system essentially consists of an anode compartment and a cathode compartment with or without a proton exchange membrane (Fig. 1). In the anode, organic substrates (electron donors) are oxidized by exoelectrogens, generating electrons and protons. The electrons are transferred to the anode material and then pass through an external electric circuit to the cathode. At the same time, protons diffuse from the anode to

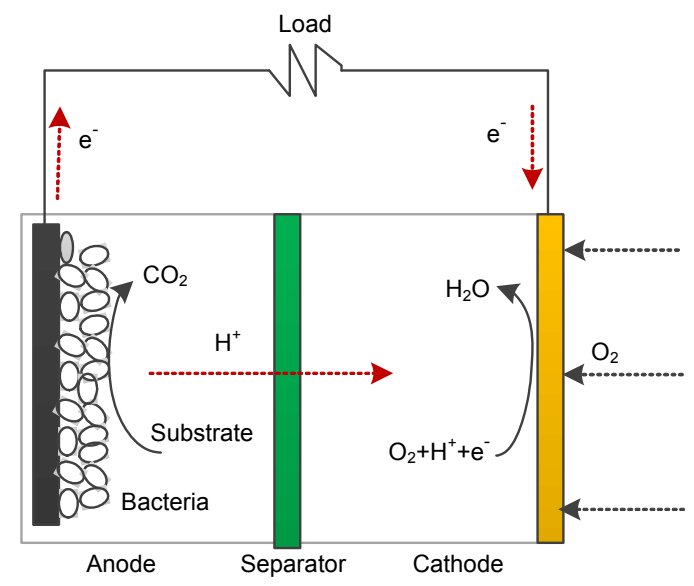

Fig. 1 Schematic diagram of the working principle of MFCs for electricity production and pollutant degradation the cathode through the electrolyte and membrane in order to achieve electroneutrality. At the cathode, a terminal electron acceptor, such as oxygen, nitrate, or sulfate, accepts the electrons and combines with protons to produce new reduced products. MFCs can generate electricity from nearly all sources of biodegradable organic matter in wastewaters, including simple molecules such as acetate, ethanol, and glucose, and polymers such as polysaccharides, proteins, and cellulose (Rabaey and Verstraete, 2005; Pant et al., 2010).

The MFC technology has many advantages that make it a promising sustainable pattern of wastewater treatment (Pant et al., 2012). However, its practical application in wastewater treatment has not been realized. Great challenges from low power output, high capital cost, and other system limitations exist and need to be overcome. There have been many excellent review papers published regarding the application of MFCs in wastewater treatment (Du et al., 2007; Rismani-Yazdi et al., 2008; Rozendal et al., 2008a; Logan, 2010; Pant et al., 2010; Oh et al., 2010; Lefebvre et al., 2011; Li et al., 2014). In this perspective, we will focus on the important opportunities and challenges of MFCs for sustainable wastewater treatment. The scaling-up of MFCs and the integration of MFCs with other relevant technologies are especially discussed. We aim to offer some valuable information about the key issues in the development of MFCs, and to stimulate more thinking and discussion regarding what needs to be done in the future to promote the practical applications of MFCs in wastewater treatment.

\section{MFCs for sustainable wastewater treat- ment: opportunities and challenges}

A sustainable wastewater treatment process should essentially features: neutral-energy operation, minimal adverse environmental impact, balanced investment and economic output, stable treatment performance, high effluent quality to meet water reclamation and reuse requirements, little resource consumption, and good social equity (Levine and Asano, 2004; Muga and Mihelcic, 2008). Treatment of domestic wastewaters using conventional processes, such as activated sludge approach, membrane 
bioreactor and anaerobic digestion, is usually hard to achieve sustainability, because of their high energy consumption, adverse environmental impacts and/or low effluent quality. For example, a conventional activated sludge process requires $0.3 \mathrm{kWh} / \mathrm{m}^{3}$ for aeration (McCarty et al., 2011), and generates 0.40.8 g-VSS (volatile suspended solids)/g-COD. Membrane bioreactors demand a high energy input of 1 to $2 \mathrm{kWh} / \mathrm{m}^{3}$ for an appropriate treatment efficiency and high effluent quality (Nowak and Fimml, 2011). Although anaerobic digestion of sludge has achieved energy neutrality by producing biogas (methane) in some wastewater treatment plants, its sustainability is limited due to the requirement for a high organic load $\left(>3 \mathrm{~kg}\right.$ organic matter per $\left.\mathrm{m}^{3}\right)$ and warm temperature $\left(>20^{\circ} \mathrm{C}\right)$, resulting in low effluent quality, and high operational cost (Nowak and Fimml, 2011). As an emerging technology, MFCs are, due to their many unique advances, a promising candidate for realizing the sustainability in wastewater treatment.

First, MFCs are theoretically energy profitable, based on their low energy consumption and direct electricity generation. MFCs are considered an energy-saving technology due to their needless of aeration or temperature maintenance, and their low excess sludge generation compared to the conventional activated sludge process (Rozendal et al., 2008a; Oh et al., 2010; He, 2013). Only about $0.024 \mathrm{~kW}$ or $0.076 \mathrm{kWh} / \mathrm{kg}-\mathrm{COD}$ on average (mainly for reactor feeding and mixing) was estimated to be consumed in MFCs (Zhang F. et al., 2013b), compared to about $0.3 \mathrm{~kW}$ or $0.6 \mathrm{kWh} / \mathrm{kg}$-COD for the activated sludge-based aerobic process (McCarty et al., 2011). More importantly, MFCs are capable of directly producing electricity from the organic matter in wastewater with a high energy conversion rate, whereas the conversion of biogas (e.g., $\mathrm{CH}_{4}$ or $\mathrm{H}_{2}$ ) into electricity causes a significant energy loss of more than $60 \%$ (Rittmann, 2008).

Second, MFCs have a low adverse impact on the environment. MFCs are capable of efficiently removing a large variety of contaminants from wastewaters, such as nutrients (Min et al., 2005b), recalcitrant cellulose (Aulenta et al., 2011; Kalathil et al., 2011), dyes (Liu et al., 2009; Mu et al., 2009), leachates (You et al., 2006a), volatile fatty acids (Freguia et al., 2010), metals (Li et al., 2008; Zhang B. et al., 2009a) and nitrate and sulfur compounds
(Rabaey et al., 2006; Zhao et al., 2009; Yan et al., 2012; Zhang and He, 2012). A good effluent quality with $\mathrm{COD}<20 \mathrm{mg} / \mathrm{L}$ can be achieved by MFCs with an optimized reactor configuration and operating condition (Yu et al., 2012). Moreover, the low energy consumption of MFCs results in low fossil-related $\mathrm{CO}_{2}$ production. MFCs also have a low sludge production of about $0.1 \mathrm{~g}-\mathrm{VSS} / \mathrm{g}-\mathrm{COD}$, which is much lower than that produced in activated sludge systems (0.4-0.8 g-VSS/g-COD) (Foley et al., 2010; Zhang F. et al., 2013b). Therefore, the secondary pollution risks and extra energy consumption associated with sludge disposal are greatly reduced.

Third, MFCs have theoretically a good operational stability and low operational cost. The microbes in MFCs have a good resistance to toxic substances and fluctuations in $\mathrm{pH}$ (Borole et al., 2011). MFCs can also operate over several different temperature ranges, ranging from ambient temperatures $\left(15-35^{\circ} \mathrm{C}\right)$ to both high temperatures $\left(50-60{ }^{\circ} \mathrm{C}\right)$ and low temperatures $\left(<15^{\circ} \mathrm{C}\right)$ (Larrosa-Guerrero et al., 2010). Theoretically, an MFC could gain an economic revenue of about $0.0005 \mathrm{USD} / \mathrm{kg}-\mathrm{COD}$ based on a net energy recovery rate of $0.004 \mathrm{kWh} / \mathrm{kg}-\mathrm{COD}$ and an average electricity price of $0.12 \mathrm{USD} / \mathrm{kWh}$. In contrast, the treatment cost for an activated sludgebased WWTP is about $0.12 \mathrm{USD} / \mathrm{kg}$-COD given an energy consumption of $0.6 \mathrm{kWh} / \mathrm{kg}-\mathrm{COD}$ (McCarty et al., 2011).

Despite these theoretical advances, the application of MFCs in real-world wastewater treatment is currently far from successful. The biggest challenge is the relative low power production level of MFCs, especially for those at larger scales. This makes it hard to realize the energy and economic revenues. Although a maximum volumetric power density of $2.87 \mathrm{~kW} / \mathrm{m}^{3}$ (normalized to the fuel cell volume) has been achieved in a $30 \mathrm{ml}$ MFC with a cloth electrode assembly configuration (Fan et al., 2012), the value decreased substantially (typically to less than $35 \mathrm{~W} / \mathrm{m}^{3}$ ) when the fuel cell size was increased from milliliter-scale to liter-scale (Dekker et al., 2009). It has been suggested that MFCs should have to be able to produce at least $400 \mathrm{~W} / \mathrm{m}^{3}$ to be competitive with traditional anaerobic digestion (Pham et al., 2006), and to have an output of $1 \mathrm{~kW} / \mathrm{m}^{3}$ (at an organic loading rate of $\left.10 \mathrm{~kg}-\mathrm{COD} /\left(\mathrm{m}^{3} \cdot \mathrm{d}\right)\right)$ to achieve energy self-sufficiency (Rabaey and Verstraete, 2005). It is 
clear that there is much room for the MFC technology to improve its power production level. In addition to low power generation, other factors, such as high capital cost, low power harvesting efficiency and poor long-term system stability, are also challenging the real-world application of MFCs in wastewater treatment (Fig. 2).

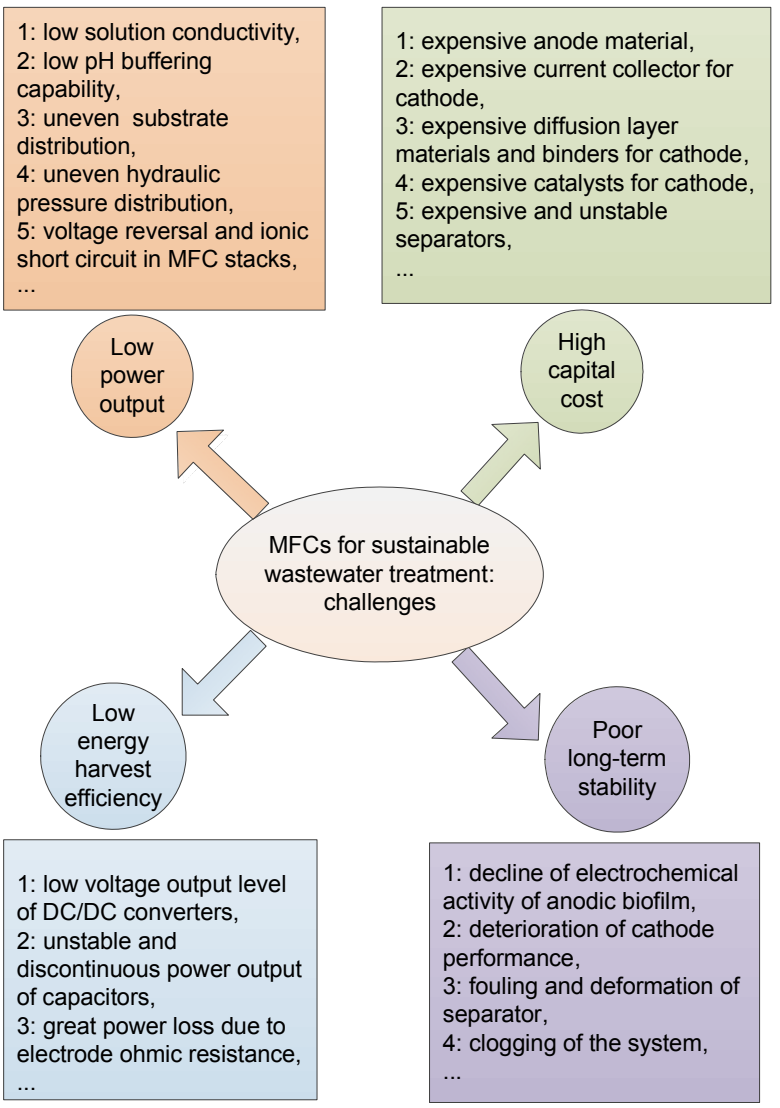

Fig. 2 Challenges of MFCs for real-world sustainable wastewater treatment

During the past decades, much laboratory work has been conducted on milliliter-scale MFCs (Logan, 2010), which provides valuable guidance for the future development of commercial MFCs. However, it is not advisable to design practically-used MFCs along the lines of the laboratory ones, because there are many differences between the laboratory and the real-world conditions. For example, most laboratory experiments for MFC study use a defined substrate (sodium acetate in most cases), controlled solution chemistry, and stable operation temperature, but the actual wastewaters, both municipal and industrial, are much more complex. The components of wastewaters are complicated and may contain some undegradable or even toxic substances which will hinder the electrochemical activity of anodic microorganisms. Wastewaters are usually poorly buffered which will lead to an accumulation of $\mathrm{H}^{+}$in the anode and $\mathrm{OH}^{-}$in the cathode region; the conductivity of real wastewaters is usually too low to maintain a low internal resistance; in many regions the ambient temperature may change dramatically at different times of the day and in different seasons of the year, which makes it hard to always maintain a high performance of the anode bacteria. The components and chemistry of wastewaters may also change over time depending on changes in the production processes of factories, sudden rainfall or sudden influx of unexpected chemicals. All these factors need to be considered when we design and operate a MFC system for wastewater treatment.

In order to realize the real-world application of MFCs in wastewater treatment, system scaling-up is inevitable. Large-scale MFCs can act as a standalone technique for wastewater treatment and energy production, or they can be combined with other processes to form a synergic system. This latter strategy is capable of realizing many specific purposes, e.g., for a high effluent quality or for recovering more commercial value from wastewaters, and thus has been proposed as a more promising way for future wastewater treatment (Li et al., 2014). However, with a continuing improvement in both technique and material aspects, we believe it is also possible in some instances to achieve sustainable wastewater treatment by using the MFC technique alone. Moreover, a good performance of large-sized MFCs is the corner-stone of any MFC-based synergic system. In the following, we will first introduce the key issues and propose future development directions for the scaling-up of MFCs. Afterwards, we will discuss several possible approaches for the integration of MFCs with other processes for sustainable wastewater treatment.

\section{Scaling up MFCs to a practical level}

It would be ideal to get a practical level of both energy output and wastewater treatment efficiency when the reactor size of MFC is enlarged from milliliter to liter or cubic meter scale. However, limitations such as low power output, high capital cost, power 
management problems, and poor long-term stability of the system are challenging the scaling up of MFCs. Only few studies on overcoming these limitations have been done. We will discuss how to manage the critical factors limiting the scaling up of MFCs and will propose approaches to the challenges posed in the following section.

\subsection{Increasing power output}

There are two strategies for making large-scale MFCs for wastewater treatment: enlarging the size of an individual reactor and combining MFC units as a stack.

\subsubsection{Enlarging reactor size}

When the MFC is scaled up to several liters or more, the volumetric power density can be $2-4$ orders of magnitude lower than that of laboratory-scale MFCs (Liu et al., 2008; Clauwaert et al., 2009; Logan, 2010; Cheng and Logan, 2011). Previous scaling up efforts provide us valuable information for understanding the reasons for this low power output from large-scale MFCs, which should be considered in for future reactor design. It has been proposed that one of the main reasons for power loss upon scaling up of MFCs is the increase in internal resistance (Clauwaert et al., 2008a). Internal resistance can be reduced by decreasing the spacing of the electrodes or by increasing the solution conductivity (Liu et al., 2008). A close distance between the anode and the cathode is important for reducing the solution resistance and $\mathrm{pH}$ gradient in large-scale MFC systems (Fornero et al., 2010). However, possible short circuits and increased oxygen diffusion to the anode decrease power output when the electrodes are too close. So a separator which prevents electrode contact and oxygen diffusion is recommended to keep the electrodes spaced and the internal resistance small. However, the separator can also inhibit proton transfer and lead to $\mathrm{pH}$ gradients between the electrode chambers thus increasing the internal resistance. The offsetting needs of reducing oxygen transport but facilitating proton transport make it difficult to design separators. Low-cost cloths have been recommended to replace expensive membranes as an effective separator for large-scale applications. A cloth-electrodes assembly configuration has proved to enable reducing the anode-cathode spacing to $0.6 \mathrm{~mm}$ while greatly en- hancing power generation (Fan et al., 2012). However, cloths may gradually be degraded by the microorganisms in the system, thus impairing the long-term stability of MFCs. Non-biodegradable and low cost separators with low oxygen permeability and high proton transmission rates need to be developed.

Solution chemistry is another important factor affecting the internal resistance and thus the power output of MFCs. Increasing the solution conductivity and $\mathrm{pH}$ buffering capability has proved effective in improving the power density of large-sized MFCs. For example, increasing the ionic strength of a $520 \mathrm{ml}$ MFC from 100 to $300 \mathrm{mmol} / \mathrm{L}$ increased power output by $25 \%$ (Liu et al., 2008). In a $20 \mathrm{~L}$ stacked two-chamber MFC, the cathode performance was improved by decreasing the $\mathrm{pH}$, aerating the catholyte with pure oxygen instead of air, and increasing the flow rate, resulting in a power density increase to $144 \mathrm{~W} / \mathrm{m}^{3}$ (Dekker et al., 2009). Balancing $\mathrm{pH}$ by a complete liquid loop over cathode and anode (Clauwaert et al., 2009), or acidifying the catholyte of two-chamber MFCs (Zhang F. et al., 2010) also increased power generation. However, real domestic and industrial wastewaters are generally poorly conductive or $\mathrm{pH}$ buffered. Hence, it is a critical problem to maintain a high performance of MFCs under such conditions. Addition of chemicals, such as $\mathrm{NaCl}$, bicarbonate and phosphate buffered saline, may be useful in lab-scale studies, but it is not sustainable for large-scale real-world wastewater treatment. We propose here that using a close electrode assembly configuration to offset the high internal resistance caused by the low conductivity of the solution, and increasing the solution flow rate or stirring intensity to alleviate the $\mathrm{H}^{+} / \mathrm{OH}^{-}$accumulation on anodes/cathodes to make up for the poor $\mathrm{pH}$ buffering capability of actual wastewaters may be needed.

To minimize internal resistance, the electrode overpotentials should also be reduced. Reducing electrode overpotential can be achieved by increasing the surface area or surface reactivity of electrode materials. Increasing the surface area of the anode can significantly increase power density in a smaller fuel cell (28 ml) (Logan et al., 2007), but it did not appear so important in larger MFCs (Cheng and Logan, 2011). In contrast, the surface area of the cathode is the limiting factor for power production in large-scale MFCs. Cheng and Logan (2011b) demonstrated that 
in a $1.6 \mathrm{~L}$ air-cathode MFC, doubling the cathode size can increase power output by $62 \%$ with domestic wastewater, but doubling the size of the anode increased power output by only $12 \%$. The volumetric power density of MFC was linearly related to the specific surface area of the cathode, and independent of the fuel cell size or configuration.

When the MFC becomes large, it may not be easy to maintain "homogeneity" in the reactor. The "inhomogeneity" in large-sized MFCs is revealed by different substrate concentrations and hydraulic pressures in different parts of the reactor. (i) An uneven distribution of substrate can affect the mass transfer rate, electrochemical reaction rate and finally electricity production. Increasing the mixing intensity by increasing the hydraulic retention time, the internal recirculation flow rate and/or the aeration flow rate would be useful in achieving a homogenous distribution of the substrate for large-sized MFCs (You et al., 2006b; Chen et al., 2008; Cha et al., 2010; Oh et al., 2010). However, adverse effects such as anodic biofilm detachment and low pollutant removal efficiency may occur when the flow rate is too high. Hence, it is necessary to design an optimal flow rate, at which the substrate is homogenously distributed, the system is not seriously disturbed, and the wastewater treatment efficiency is appropriate. (ii) In large-sized MFCs, an electrode may experience quite different hydraulic pressures at different water depths. For instance, the bottom of an upright electrode of $1 \mathrm{~m}$ height would experience a hydraulic pressure $98 \mathrm{kPa}$ higher than the top area. Our laboratory has studied the effect of hydraulic pressure on the performance of single-chamber air-cathode MFCs (Cheng et al., 2014a). Results showed that the power density of the MFC decreased by $24.4 \%$ and $44.7 \%$ as the hydraulic pressure increased to from $100 \mathrm{~mm} \mathrm{H}_{2} \mathrm{O}$ to $500 \mathrm{~mm} \mathrm{H}_{2} \mathrm{O}$ and $2000 \mathrm{~mm} \mathrm{H}_{2} \mathrm{O}$, respectively. The high hydraulic pressure suppressed the performance of both the cathode and the anode. Hydraulic pressure had no effect on the microbial community of anodic biofilms. However, the metabolism and electrochemical activity of exoelectrogenic bacteria were found to be temporarily suppressed by high hydraulic pressures. The decreased cathode performance under high hydraulic pressures arose from water flooding of the catalyst layer, resulting in an increase in both charge transfer resistance and diffusion resistance.
Thus, in order to obtain a high performance of large-sized MFCs, effective strategies for improving the electrode performance of MFCs under high hydraulic pressures are very much required. To this end, culturing pressure-resistant anodic exoelectrogenic bacteria and developing a new cathode structure with less water-flooding under high hydraulic pressures should be conducted.

\subsubsection{MFC stacks}

As mentioned above, a variety of challenges exist in the scaling up of individual MFCs, which may prevent the reactor size being as large as the existing treatment systems. An alternative, which may be a more feasible option for MFC scaling-up, is to construct stacks of moderately-scaled MFC units. In order to practically apply MFCs as an energy source, one can connect MFC units in parallel to produce a higher current or in series for a higher voltage. Aelterman et al. (2006) connected six MFCs in parallel, which resulted in a current equal to the sum of the individual MFCs, while the voltage was similar to the average of the individual MFCs. Furthermore, the maximum power density of parallel-connected MFCs can be several times greater than that of the single MFC unit (Ieropoulos et al., 2008; Wang and Han, 2009). With connection in series, it would be ideal that the output voltage equals the sum of the voltages of the individual MFCs, and the current would be at the average of the individual reactors. However, MFCs may experience cell voltage reversal and ionic short circuits, making the series stack efficiency as low as 38\%-41\% (Ieropoulos et al., 2008; Wang and Han, 2009). Voltage reversal results from unequal electrode potentials between the unit cells, probably due to insufficient distribution of the substrate (Kim et al., 2012). Voltage reversal can be prevented by using air cathodes of high parallelism in performance, maintaining similar catalytic activity of anode biofilms, and increasing the homogeneity of substrate distribution in different unit cells. However, much work is still needed to turn these strategies into reality. The ionic short circuit occurs when the same anolyte or catholyte is shared by different MFCs in serialconnection (Ledezma et al., 2013). Separating the anolyte of the unit cells might be useful to prevent ionic short circuits, but it would increase the costs of reactor construction and maintenance. A promising 
development direction for the MFC stack is to create an electrical array to multiply connect the MFC units both in series and in parallel. In this way, both the cell voltage and current can be boosted and the substrate can be sufficiently degraded. However, researches in this aspect are still few, and research effort is required to better understand the interplay between individual MFC units, to optimize the connection mode for the maximum power output, and to maintain the stability of the complex stack system.

\subsection{Reducing capital cost}

Another critical problem hindering the largescale application of MFC is its high capital cost, which mainly arises from the expensive construction materials. Reducing the capital cost can be achieved by using highly efficient, scalable and less-expensive anode, cathode and separator materials. Electrodes that contain current collectors are now considered a suitable configuration, due to their simple structure and effective current collection. For the anode, one of the most promising electrode structures is a graphite fiber brush, which is made by incorporating graphite fibers into a non-corrosive metal core (certain stainless steels or titanium). Metals such as tungsten and stainless steel can also be used in brush form. Another promising anode material is activated carbon (AC) granules, especially when linked to a metal mesh current collector. An anode chamber stacked with AC has a high specific surface area (area per mass) for bacterial growth and electricity production. However, much remains to be known about the distribution of microbes, and the proton and electron transfer mechanisms inside the AC stack, and the fuel cell configuration needs be optimized for a better performance.

The price of cathode materials accounts for the greatest percentage $(47 \%-75 \%)$ of the MFC capital cost (Rozendal et al., 2008a). The most promising cathode form for future MFCs is that using oxygen in the air as the terminal electron acceptor (the aircathode), based on the readily available nature of oxygen in the air and the absence of a need for solution aeration. Reducing the cost of the air-cathode can be achieved by developing inexpensive current collection materials, diffusion layer materials, binders, and catalysts. A promising current collection material is the metal mesh, such as a stainless steel mesh and nickel foam, which is low cost and highly-conductive. Low-cost poly-tetrafluoroethylene (PTFE) and polydimethylsiloxane (PDMS) can be used as the oxygen diffusion layer and catalyst binder instead of the expensive Nafion. Low cost catalysts with non-precious metals, such as CoTMPP, $\mathrm{MnPc}, \beta-\mathrm{MnO}_{2}$, Co-OMS-2, $\mathrm{MnO}_{x}$, and $\mathrm{Co} / \mathrm{Fe} / \mathrm{N} / \mathrm{CNT}$ (Zhou et al., 2011) can be used instead of the expensive Pt. An especially interesting catalyst is activated carbon, which is low cost and has a high catalytic activity. However, the mechanism how the activated carbon catalyzes oxygen reduction remains unclear (Watson et al., 2013). Another difficulty in reducing the cost of cathodes is the requirement of a complex gas-liquid-solid threephase interface for oxygen reduction, which makes the selection of cathode material and design of cathode structure more challenging.

The separator is another costly component of MFCs. Although it has been proved that the absence of a separator in small MFCs favors low internal resistance and low capital cost (Liu and Logan, 2004), in large-sized MFCs it is usually necessary to construct close electrode spacing for a low internal resistance, and thus a separator is essential to prevent electrode contact and oxygen crossover to the anode. From the economic point of view, expensive membranes, such as ion exchange membranes, ultra filtration membranes, and forward osmosis membranes are not suitable for use in large-scale MFCs. A promising low-cost separator material is non-woven cloth (Fan et al., 2012; Wang et al., 2013), but its mechanical strength and long-term stability still need to be improved. The development of low cost, proton transferable, and long-term stable separator materials is very important for large-scale MFCs in the future.

\subsection{Managing power output}

How to efficiently harvest the electrical energy is another critical issue in the scaling up of MFCs. It is difficult for an MFC to directly support a practical load, even at the maximum power generating point, due to the low voltage and current level (Kim et al., 2011). Thus, a power management system (PMS) is needed to be incorporated into MFCs to make the energy feasible for powering electrical devices, e.g., wireless sensors to monitor the environment (Donovan et al., 2011; Zhang F. et al., 2011b). 
Although using an optimal resistor (resistance value equal to the internal resistance) makes MFCs capable of producing their maximum power density, resistors cannot harvest energy because the generated electricity is dissipated as heat instead of being utilized or stored. For efficient harvesting and usage of MFC energy, a DC/DC voltage boost converter and various electric-storage capacitors have been tested. DC/DC voltage boost converters can extract energy from MFCs by a high frequency switching action (Park and Ren, 2012a). Park and Ren (2012a) have demonstrated that the operating voltage of MFCs can be easily maintained at the maximum power point and the output voltage can be boosted to a standard level of $1.5 \mathrm{~V}$ or $3.3 \mathrm{~V}$ using a separate boost converter to support electronic loads. After using a metal oxide semiconductor field effect transistor to replace the traditional diode of the converter, the harvesting efficiency of the synchronous boost converter can reach 75.9\% (Park and Ren, 2012a). However, there still much room to raise the energy harvesting efficiency and the voltage output level. Optimization of the electronic circuit of the converter and developing a maximum power point tracking technique (Park and Ren, 2012b) could be promising strategies for this purpose. When a capacitor is connected to a MFC it stores energy from the MFC and waits until a desired amount of energy is stored, then discharges the energy. It has been reported that connecting a capacitor to a sediment microbial fuel cell (SMFC) enabled the SMFC to produce $2.5 \mathrm{~W}$ power, which could be used to operate a wireless sensor (Donovan et al., 2011). Another study showed that parallel charging of multiple capacitors can avoid potential voltage reversal and discharging the capacitors in series produced up to $2.5 \mathrm{~V}$ with four capacitors (Kim et al., 2011). A great challenge for capacitor energy harvesting is that capacitors can only passively capture the energy from the MFC, so the system's performance may not be stable. Another challenging problem is that a continuous high-level power output cannot be realized by using capacitors. To overcome these drawbacks, developing more efficient capacitors by optimizing electrode materials and control systems, or designing novel combination modes between the capacitor and the MFC might prove useful.

For large-sized MFCs, it is also critical to con- sider the great power loss from the large ohmic resistance of large-sized electrodes. This is because the distance between the points where electrons are generated/consumed and the leading-out/leading-in terminals where current flows in/flows out of the electrode increases with the increase of the size of the electrodes. We have estimated the power loss and electrode potential drop distribution on the carbon mesh anode with different leading-out terminal configurations and various electrode dimensions by both modeling and experimental methods (Cheng et al., 2014b). We found that the power loss within an anode of $1 \mathrm{~m}^{2}$ can be as high as $4.19 \mathrm{~W}$ (at $3 \mathrm{~A} / \mathrm{m}^{2}$ ), which can be lowered to $0.04 \mathrm{~W}$ with an optimized leading-out terminal configuration (Fig. 3) and to $0.01 \mathrm{~W}$ by utilizing the more-conductive brass mesh as an anode material. The experimental results also showed that more than $47.1 \%$ of the power loss from moving from small-scale to large-scale MFCs came from poor leading-out terminal configurations. Therefore, optimizing the leading-out mode of the electrodes is one of the key factors for scaling up MFCs, and is an important issue in the design of large sized reactors.

\subsection{Increasing long-term stability}

Long-term stability is important for the energy balance and economic feasibility of the MFC system. A deteriorating performance of MFCs during longterm operation has been detected in many studies (Min and Logan, 2004; Chung et al., 2011; Zhang F. et al., 2011a; 2013b; Zhuang et al., 2012). Reasons for this performance decline arise from many factors, such as the decrease of electrochemical activity of anodic biofilm, the deterioration of cathode performance, fouling and deformation of separator materials, and clogging of the system by excessive biomass and solid pollutants in wastewaters.

3.4.1 Maintaining the electrochemical activity of the anodic biofilm

Maintaining the electrochemical activity of the anodic biofilm is a great challenge because the wastewater environment is complex. Factors like substrate concentration, waste components, solution temperature, acidity, and conductivity may change irregularly (Zhang Y. and Angelidaki, 2012; Zhang F. 

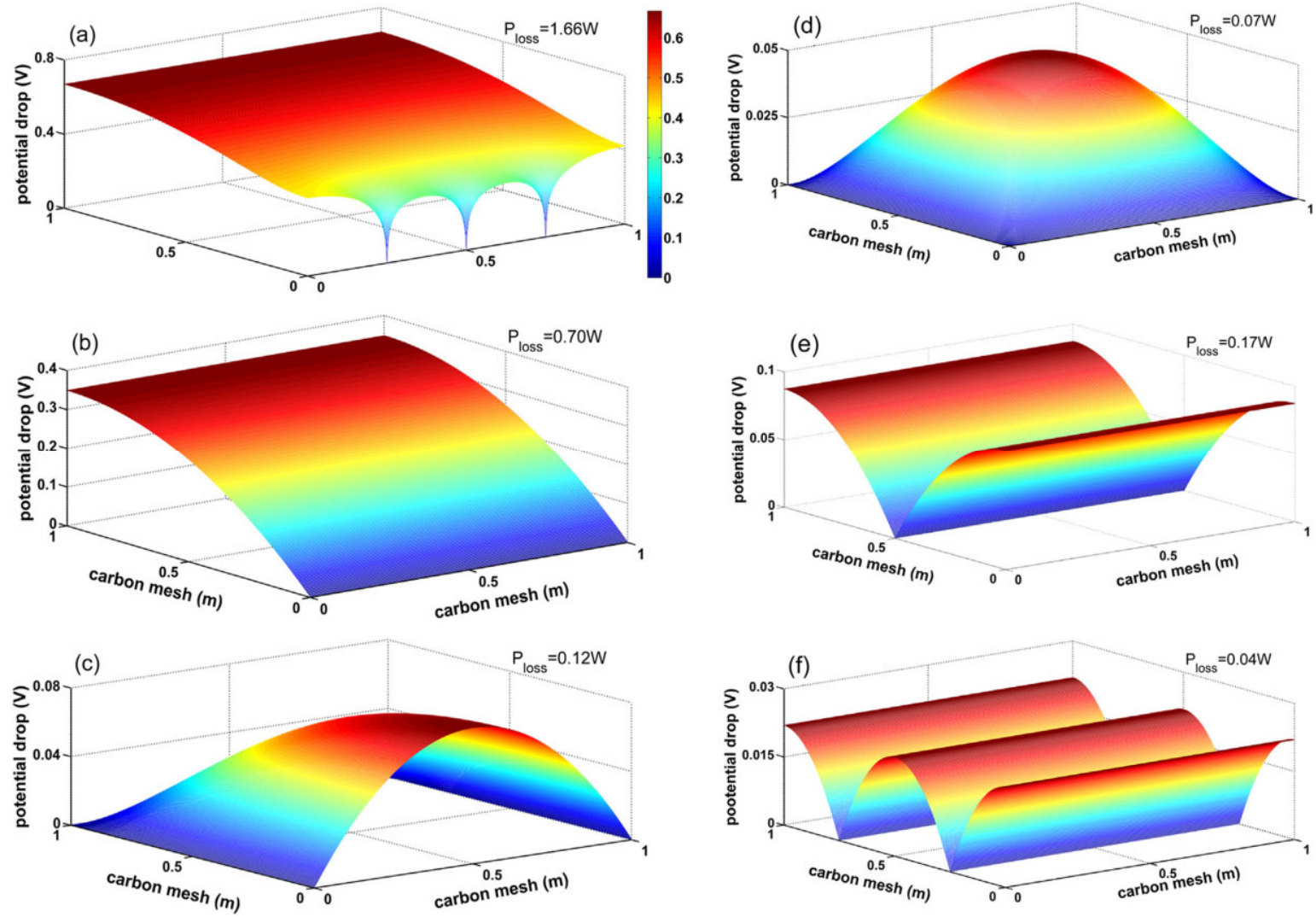

Fig. 3 Simulated potential drop distribution and power loss of different leading-out terminal configurations (a) Three nodes from one side; (b) All nodes from one side; (c) All nodes from three sides; (d) All nodes from four sides; (e) All nodes from the axis line; (f) All nodes from two 1/4 axes (Cheng et al., 2014b)

et al., 2013a) and influence microbial activity. In particular, the anodic biofilm may be seriously damaged when the wastewater contains toxic chemicals, e.g., heavy metals and antibiotics. A comprehensive understanding of the electrode microorganisms and their extracellular electron transfer behavior at both molecular level and at the level of the microbial community would be helpful for better control of the activity of anodic biofilm. However, much remains unknown in this area. Future work should especially focus on (i) understanding the electron transfer paths between the exoelectrogens and the electrode, (ii) how to increase the biofilm conductivity for a low internal resistance, (iii) understanding the relationship between the biofilm properties (e.g., community composition, biofilm thickness, porosity) and mass diffusion and electron transfer, and (iv) understanding the complex interactions between the exoelectrogens and their various syntrophic partners and competitors.

\subsubsection{Reducing the cathode deterioration}

The deterioration of cathode performance is another critical challenge for the long-term stability of MFCs (Timmers et al., 2010; Ahmed, 2011; Chung et al., 2011). This performance decline is dependent on several factors, including catalyst deactivation, biofilm pollution, substrate salting-out, and corrosion of the current collector (Fig. 4).

(i) Deactivation of oxygen reduction catalysts (ORCs) is especially critical for metal-based catalysts, such as the Pt-, Co-, and Fe-based ones. This is because metal-based ORCs are susceptible to the environmental conditions in MFCs, which may change adversely due to chemical reactions, biological activities, and changes in catholyte composition. For instance, Schmidt et al. (2001) found that when a Pt cathode was placed in a chloride-rich electrolyte, the adsorbed $\mathrm{Cl}^{-}$ions on the catalyst layer would block 
the active catalytic sites for oxygen reduction and thereby change the reaction pathway toward the production of $\mathrm{H}_{2} \mathrm{O}_{2}$. Zhao et al. (2006) have reported that the performance of a pyr-FePc cathode was reduced by $40 \%$ when the concentration of a phosphate buffer catholyte $(\mathrm{pH} 3.3)$ was lowed from 500 to $50 \mathrm{mmol} / \mathrm{L}$, and the oxygen reduction rate on a CoTMPP-based cathode was decreased by $80 \%$ when the catholyte $\mathrm{pH}$ was increased from 2.4 to 7 ( $500 \mathrm{mmol} / \mathrm{L}$ phosphate). Furthermore, catalyst poisoning caused by extracellular polymeric substances (EPS) of attached microorganisms or other ions in wastewaters may be also a great challenge for the long-term stability of ORC. The mechanism of how the activity of ORC is affected by environmental factors should be uncovered in future studies, based on which approaches to minimize catalyst deactivation should be developed.

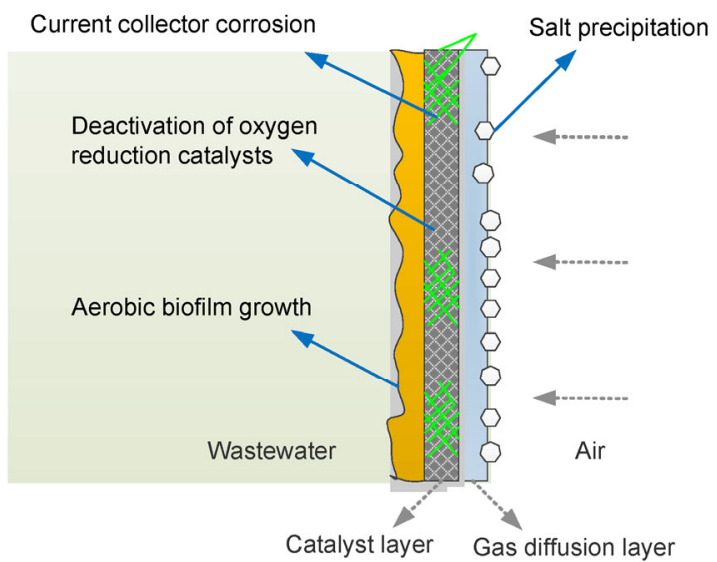

Fig. 4 Schematic diagram of various factors causing the deterioration cathode performance

(ii) Growth of biofilm on the solution-facing side of air-cathodes may reduce the long-term cathode performance, especially for single chamber MFCs (Liu et al., 2005a; Yang et al., 2009; Santoro et al., 2012; Yuan et al., 2013). Oxygen is reduced at the cathode through the reaction $\mathrm{O}_{2}+4 \mathrm{e}^{-}+4 \mathrm{H}^{+} \rightarrow 2 \mathrm{H}_{2} \mathrm{O}$ $\left(E^{0}=+1.230 \mathrm{~V}\right)$ or $\mathrm{O}_{2}+4 \mathrm{e}^{-}+2 \mathrm{H}_{2} \mathrm{O} \rightarrow 4 \mathrm{OH}^{-}\left(E^{0}=+0.40 \mathrm{~V}\right)$ depending on the catalyst selected (Yuan et al., 2013). A thick aerobic biofilm on the cathodes may function as a diffusion barrier to $\mathrm{H}^{+}$transfer to the catalyst site (Zhang X. et al., 2009; Ahmed, 2011), and it can severely block $\mathrm{OH}^{-}$transport outside the electrode, resulting in an significant $\mathrm{OH}^{-}$accumulation in the cathode microenvironment and thus a lower cathode potential (Yuan et al., 2013); the aerobic bacteria may consume a portion of the available oxygen at the catalytic sites and thus reduce the oxygen reduction kinetics (An et al., 2011; Yuan et al., 2013); the EPS of attached microorganisms may also cause catalyst poisoning. Up to now, only the mechanisms of blockage of $\mathrm{OH}^{-}$and oxygen transfer by the cathodic biofilms have been demonstrated (An et al., 2011; Yuan et al., 2013), the mechanisms how the aerobic biofilm affects cathode performance still need to be investigated. As a result of biofilm growth, an increased internal resistance coupled with a decreased electricity (power) generation of MFCs was obtained in many studies (Cheng et al., 2006; Yang et al., 2009; Zhang X. et al., 2009; Zhang F. et al., 2011a). Therefore, it is important to develop effective methods to minimize the cathode bacterial growth for a better long-term performance of MFCs. At present, only few studies have been conducted to this end (An et al., 2011; Watson et al., 2011). Promising strategies may include employing metal nanoparticles instead of $\mathrm{Pt} / \mathrm{C}$ as the cathodic catalyst (An et al., 2011), reducing oxygen transfer to the solution-facing side of the cathodes (Watson et al., 2011), incorporating bactericidal compounds (e.g., fluoroquinolones, cephalosporins, and chloramphenicols) into the catalyst layer of the cathodes, or changing the physicochemical properties (e.g., hydrophilicity or surface functional groups) of the cathodes.

(iii) Salt precipitation and current collector corrosion have been observed during the long-term running of air-cathode MFCs in our laboratory (Pan et al., 2014). Ahn et al. (2014) and Santoro et al. (2013) have also reported that salt precipitations on the cathode decreased catalyst activity and thus longterm cathode performance. However, much remains unknown about the dependence of salt precipitation on the physicochemical properties of the cathode and the components of the electrolyte. Also, the mechanisms how salt precipitation affects the catalytic activity, mass and gas diffusion, and cathodic overpotential need to be uncovered. The corrosion of current collectors, especially nickel foam, due to the complex redox environment of the cathode is also challenging. Using corrosion-resistant materials, e.g., stainless steel mesh and carbon mesh, may solve this problem, but attention should be paid to the ohmic resistance and effective surface area when selecting appropriate current collectors for the cathodes. 
3.4.3 Preventing the fouling and deformation of separators

Fouling and deformation of separator materials (e.g., membranes and various cloths) also impair the long-term stability of MFCs (Zhang X. et al., 2009; 2010; Xu et al., 2012). The mechanism how separator fouling affects the performance of MFCs is very complex because physical, chemical, and biological interactions between the contaminants and the separator all occur simultaneously during the fouling process. Extracellular polymers secreted by the attached microorganisms may block the routes for ion diffusion, inorganic salts in the solution may precipitate on the separator, and specific ions in the solution may react with the functional groups of the separator through ion exchange or complexing reactions. These factors reduce the ion-exchange capacity, conductivity, and the ion diffusion coefficients of the separator, thus increasing the internal resistance and $\mathrm{pH}$ gradient of MFCs (Xu et al., 2012). Up to now, truly effective and practical countermeasures to separator fouling are still lacking. Designing the separator material to avoid biofilm formation, prevent inorganic salt precipitation, and reduce the reaction with various ions might be useful to this end. The deformation of the separator material, which results from the water and gas trapped between the membrane and electrode, also contributes to the declining long-term performance of MFCs (Zhang X. et al., 2010). Using porous materials with high hardness, e.g., stainless steel mesh (Zhang X. et al., 2010) to press the membrane flat against the electrode has been demonstrated to be effective in easing separator deformation and increasing the long-term performance of MFCs, but it also increases the complexity and capital cost of the system.

In addition to the above-mentioned aspects, the long-term stability of MFCs also depends on many other factors. For instance, clogging of the MFC system may occur due to the excessive biomass and solid pollutants in real wastewaters. This problem is especially critical when the electrode spacing is small The ambient temperature may vary dramatically at different seasons in many regions (e.g., it can be $>35{ }^{\circ} \mathrm{C}$ in summer and $<-10{ }^{\circ} \mathrm{C}$ in winter in Beijing, China), which will affect the activity of anodic microorganisms for both electricity generation and pollutant degradation. Hence, the maintenance of a stable and effective electricity production and wastewater treatment efficiency of MFCs at all temperature levels becomes challenging. Above all, maintaining the long-term stability of MFCs during real-world wastewater treatment is a very difficult task, and we still need to do much work on this issue. Encouragingly, we have found some examples of good long-term performance (with stable operation for up to two years) of pilot-scale MFCs for realworld wastewater treatment (Zhuang et al., 2012; Zhang F. et al., 2013b). We can learn many valuable lessons from these pioneer attempts for future research.

As discussed above, sustainable wastewater treatment by MFCs requires a high power output, low capital cost, efficient energy harvesting, and longterm stability. Though large-scale MFCs are currently infeasible for practical applications due to various limitations, we believe that with concerted efforts from talented researchers around the world, and advances in fundamental research, materials engineering and system design, MFCs have the potential to become commercially viable.

\section{Synergies of MFC and other treatment technologies}

As discussed above, there are many challenges to the MFC technique before it can realize a sustainable full-scale wastewater treatment. An alternative and, perhaps, a more practical option for meeting the sustainability criterion is to combine MFC with other processes to form a synergic system. Such synergic systems take the advantages from both MFC and the coadjutant techniques while avoiding their drawbacks, and thus obtain a maximum benefit. From the sustainability point of view, one may expect to get a high effluent quality (e.g., low COD, low phosphate and nitrogen concentration, low nutrient content, and low salinity), or to extract more commercial value (i.e., produce energy-rich or highly valuable chemicals) from the wastewater. Depending on different purposes, there have been developed many types of synergic systems by combining MFCs with different techniques. In the following, we will introduce some promising MFC-based synergic modes for each purpose. At present, studies on this area are just 
emerging, and there are many challenges in system design, fundamental study, and material engineering.

\subsection{For a higher effluent quality}

A good effluent quality is an important criterion for the sustainability of a wastewater treatment process (Levine and Asano, 2004; Muga and Mihelcic, 2008). In order to meet water reclamation and reuse requirements, the effluent from a treatment process should be low in organic matter, salinity, and inorganic nutrient ions. In general, MFCs are good at treating medium- and low-strength wastewaters with a relatively simple composition. However, some actual wastewaters may contain high concentrations of organic matters, many of which are non-degradable by the microorganisms in MFCs. In some instances, strict discharge regulations require a very low concentration of phosphate and nitrogen ions in the effluent of wastewaters, which is difficult to achieve by MFC alone. Depending on the properties of wastewater and the reclamation requirements, MFC may be integrated with different traditional processes.

For high-strength wastewaters, such as brewery (Feng et al., 2008) and winery (Cusick et al., 2010) wastewaters, integration of MFC with the anaerobic digestion (AD) technique should be an attractive synergic mode (Zhang B. et al., 2009b). First, the AD reactors hydrolyze and ferment the complex substrates and particulates in high-strength wastewaters into more utilizable substrates (mainly volatile fatty acids) while producing methane or hydrogen gas. Subsequently, MFCs degrade the remaining organics in $\mathrm{AD}$ effluent to further polish the water quality and produce electrical energy. Such an AD-MFC synergic process has been demonstrated successfully in several studies (Zhang B. et al., 2009b; Sharma and Li, 2010; Durruty et al., 2012). For example, Sharma and Li (2010) integrated MFCs with an anaerobic hydrogen producing biofermentor (HPB) to simultaneously produce hydrogen and electricity from glucose wastewater (Fig. 5). This synergic system could maximally yield a hydrogen production of $2.85 \mathrm{~mol} \mathrm{H}_{2} /$ mole glucose, and a MFC power density of $4200 \mathrm{~mW} / \mathrm{m}^{3}$, with a total energy recovery efficiency of $29 \%(559 \mathrm{~J} / \mathrm{L})$ and a COD removal efficiency of $97 \%$.

To meet strict water reclamation and reuse requirements, MFCs can be integrated with a mem- brane or algae process to further reduce the effluent COD. Integration of MFCs with the membrane technology has been reported to produce high quality effluent with a turbidity $<1$ NTU and COD removal $>90 \%$ (Ge et al., 2013). Attention should be paid to the high energy consumption and high capital cost of the membrane technology. Algal treatment can be sequentially linked to MFCs to remove the residual nutrients and improve water quality, based on the great absorption capability of algae for nitrogen, phosphorus, and toxic metals (Cai et al., 2013). Zhang Y. et al. (2011) have introduced microalgae (Chlorella vulgaris) into the MFC system to remove carbon and nutrients from wastewater, and produce electricity and algal biomass simultaneously. The removal efficiencies of total organic carbon, nitrogen, and phosphorus in this MFC-algae synergic system reached up to $99.6 \%, 87.6 \%$, and $69.8 \%$, respectively, accompanied with a stable power density of $68 \mathrm{~mW} / \mathrm{m}^{2}$ and a microalgae biomass yield of $0.56 \mathrm{~kg} / \mathrm{m}^{3}$.

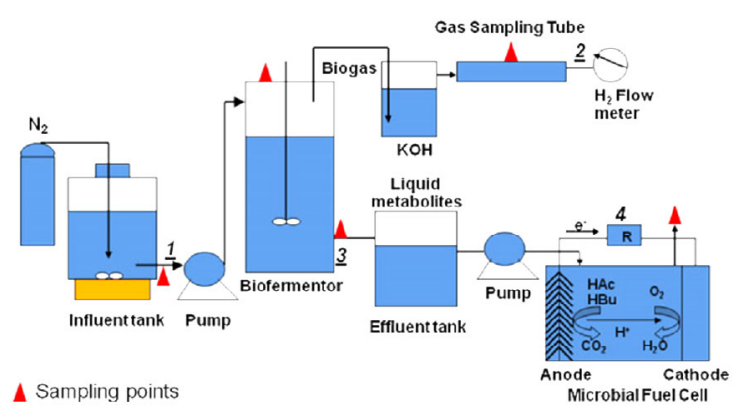

Fig. 5 Experimental setup of the continuous flow HPB and MFC synergic system (Sharma and Li, 2010)

For industrial wastewaters with high salinity, it would be attractive to integrate MFCs with the electrodialysis technique to form microbial desalination cells (MDCs) (Cao et al., 2009; Chen et al., 2011; Jacobson et al., 2011), which can simultaneously remove ionic species and generate electricity from the wastewater. A MDC is constructed by incorporating one or several pairs of anion exchange membrane (AEM) (next to the anode) and cation exchange membrane (CEM) (by the cathode) in a MFC (Cao et al., 2009). Wastewaters of high salinity are injected into the chamber between the membranes and those with low salinity into the anode and cathode chambers. When current is produced through anodic 
bacterial oxidation and cathodic reduction, negatively charged species (anions) migrate from the middle chamber to the anode, and positively charged species (cations) move to the cathode chamber. As a result, salt concentration in the high salinity wastewater can be greatly reduced during the electricity production process. At present, MDCs are primarily used for the desalination of seawater, and little is known about their suitability for high salinity wastewaters. Unlike seawater, industrial high salinity wastewaters may contain very complex organic and inorganic components besides the salt ions, which may cause severe membrane fouling and system clogging. The poor durability and high price of membranes are also great challenges for the practical application of MDCs for wastewater treatment.

Despite the tempting superiorities of MFC-based synergic systems, there is still a long way to realize their practical implementation in wastewater treatment at the present stage. The first challenge is the high cost and low performance of large-scale MFCs (as discussed in Section 3) which will limit the pollutant removal efficiency, energy balance, and economic feasibility of the system. Moreover, the complex synergic treatment process will increase the difficulties of system design, process optimization, and maintenance. The performances of different treatment steps interrelate, and any problem in one of the steps will lead to poor performance of the whole system. Hence, much needs to be done in the future regarding how to monitor and control the performance of the functional units of the system, how to increase the system's shock-resistance toward sudden changes in pollutant components, temperature and organic loading, and how to increase the long-term stability of the synergic system.

\subsection{To extract more commercial value}

MFCs can be integrated with electrochemical reduction technology to produce energy-rich and commercially valuable chemicals, i.e., $\mathrm{H}_{2}, \mathrm{CH}_{4}, \mathrm{H}_{2} \mathrm{O}_{2}$, acetate, and ethanol other than electrical power during wastewater treatment (Harnisch and Schroder, 2010; Pant et al., 2012). Such devices are called MXCs, where X stands for different types and applications (Harnisch and Schroder, 2010). MFCs and MXCs share the common element: the microbial anode, but the cathode of MXCs fulfills different tasks rather than just reduction of $\mathrm{O}_{2}$ to $\mathrm{H}_{2} \mathrm{O}$. A schematic diagram of the concept of MXC for both wastewater treatment and chemical production is shown in Fig. 6. In the following, we will introduce some important cathode tasks, analyze their major advantages and limitations, and propose promising development directions in each area.

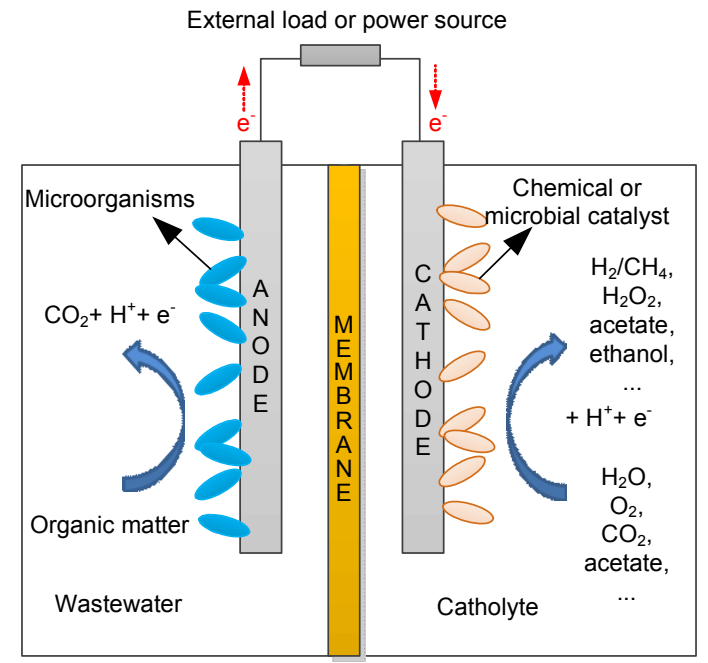

Fig. 6 Schematic diagram of the concept of MXC for simultaneous wastewater treatment and chemical production

The most studied cathode reaction is the hydrogen evolution reaction in microbial electrolysis cells (MECs). MECs function similarly to the air-cathode MFC, except that hydrogen is generated at the cathode instead of water, and an external voltage (minimum $0.13 \mathrm{~V}$, generally $-0.25 \mathrm{~V}$ or more) is added to reach the reduction potential of hydrogen and to produce $\mathrm{H}_{2}$ at sufficiently high rates (Liu et al., 2005b; Rozendal et al., 2007; Selembo et al., 2009). This voltage is very low compared to that in the traditional electrolysis of water, which generally needs a voltage input about $1.8-2.0 \mathrm{~V}$, making MEC an attractive technique for hydrogen production (Rozendal et al., 2006). Indicators in evaluating the performance of MEC mainly include hydrogen yield, hydrogen recovery efficiency, energy input, product purity, and system stability (Liu et al., 2008). A high $\mathrm{H}_{2}$ recovery efficiency of $96 \%$ has been obtained in a lab-scale MEC using acetate as the substrate at an applied voltages of $0.8 \mathrm{~V}$ (Call and Logan, 2008). However, at present only limited information is available on the application of MECs in real-world wastewater treatment and $\mathrm{H}_{2}$ production. 
One of the critical factors determining the performance of MECs is the cathode catalyst. An ideal $\mathrm{H}_{2}$ evolution catalyst should be of high catalytic activity, low cost, high selectivity, and super stability. Platinum is the first and most widely used cathode catalyst for $\mathrm{H}_{2}$ production (Rozendal et al., 2006). Despite its high catalytic activity, its high price and low selectivity limit the practical application of platinum. Alternative low cost metal catalysts are now under investigation, such as nickel alloy (Selembo et al., 2009), stainless steel (Call and Logan, 2008; Selembo et al., 2009), and tungsten carbide (Harnisch, et al., 2009), but their catalytic activity and selectivity need to be raised. Another promising type of catalyst for $\mathrm{H}_{2}$ production is microorganisms on the cathode (Rozendal et al., 2008b) which have the advantages of low cost and high operational sustainability. However, the mechanism for bacteria-catalyzed $\mathrm{H}_{2}$ production is still unclear and the catalytic performance of bacteria is still much lower than that of the chemical catalysts (Xu et al., 2014).

During MEC operation, hydrogen may be lost from the cathode chamber, decreasing the hydrogen yield and recovery efficiency. The loss of hydrogen can occur through several processes: (i) diffusion to the anode chamber through the membrane; (ii) abiotic conversion of hydrogen to methane; and (iii) degradation of hydrogen by some cathodic microbes. Thus, it is a challenging task to reduce the hydrogen loss to achieve high MEC performance. Another challenge for the application of MECs is the requirement of an external energy supply to increase hydrogen production. The theoretical minimal applied voltage for $\mathrm{H}_{2}$ production in MEC is $0.114 \mathrm{~V}$. However, this value increases to $0.8-1.0 \mathrm{~V}$ due to various energy losses in real MEC systems. It has been proposed that the applied voltage needs to be lower than $0.6 \mathrm{~V}$ in order to achieve a positive energy balance from an MEC (Lee and Rittmann, 2010). In future applications, MECs may combine with other techniques, such as dark fermentation, to achieve a greater $\mathrm{Bio}-\mathrm{H}_{2}$ yield than an MEC alone. The fermentation process can degrade complex biomass into simple organic products that can be utilized by MECs. Such combination will make it possible to effectively produce $\mathrm{H}_{2}$ from complex organic compounds from a variety of wastewaters, such as animal wastes or farming residues (Wang et al., 2011).
The production of methane in the cathode of MECs frequently coexists with the production of $\mathrm{H}_{2}$ (Cusick et al., 2010; Hamelers et al., 2010). This will reduce the commercial value of $\mathrm{H}_{2}$ and increase the energy and economical cost for its purification (Pant et al., 2012). A new perspective on this issue is to use MECs to produce methane as an alternative energy source. Methane can easily be stored or transported by mature technologies (Cheng et al., 2009). Methane-producing MECs are a promising approach for polishing digester effluents, due to their low sludge production and no aeration cost (Clauwaert and Verstraete, 2009). Several studies have reported the production of methane by reduction of $\mathrm{CO}_{2}$ at the biocathode of MECs through electro-methanogenesis (Cheng et al., 2009; Clauwaert and Verstraete, 2009; Lovley, 2011). However, the source of the electrons for methane production remains controversial. It has been suggested that methanogens may accept electrons directly from the cathode (Cheng et al., 2009; Lovley, 2011), but other studies propose that methanogens may use the hydrogen produced in the system for methane generation (Clauwaert et al., 2008b; Tartakovsky et al., 2009). Further molecular biological studies should be made to uncover the metabolic pathway of the methanogens in methane production. Other challenges for methane production include its low production rate and purity, severe loss due to its high solubility (approximately $25 \%-50 \%$ ) at moderate temperatures, and the requirement for methane removal from the effluent to avoid the greenhouse effect. For a real-world large-scale application, how to efficiently collect the methane gas and how to maintain the long-term stability of the system are also critical problems.

Beside hydrogen and methane gases, cathode reactions of MFCs or MECs can also be used to produce a variety of valuable compounds. Such examples include hydrogen peroxide, caustic soda, acetate, 2-oxobutyrate, and ethanol. Hydrogen peroxide, an important industrial chemical, can be produced at the cathode through the reduction of oxygen (Rozendal et al., 2009). A life-cycle analysis suggests that production of hydrogen peroxide in MECs is more sustainable than traditional manufacturing routes (Foley et al., 2010). The most critical challenge for hydrogen peroxide production by cathodic oxygen reduction is the difficulty of selecting a suitable catalyst. 
Caustic soda can also be produced at the cathode by making use of alkalization of the catholyte during oxygen reduction (Rabaey et al., 2010). A NaOH concentration as high as $1 \mathrm{~mol} / \mathrm{L}$ in the cathode has been achieved in a liter-scale bioelectrochemical system using acetate and brewery wastewaters in the bioanode (Rabaey et al., 2010). As in the case of hydrogen peroxide, how to select a suitable catalyst is a great challenge for the long-term stable production of caustic soda, because a high concentration of caustics impairs the catalytic activity.

Cathode reactions can also be used to produce a variety of organic chemicals via microbial electrosynthesis, in which microorganisms reduce $\mathrm{CO}_{2}$ or organic matter with electrons donated from the electrode (Rabaey and Rozendal, 2010). It has been reported that acetate and 2-oxobutyrate can be produced by biofilms of Sporomusa ovata through the reduction of $\mathrm{CO}_{2}$ with the cathode as the sole electron donor (Nevin et al., 2010). Ethanol can be produced from the oxidation of glycerol by engineered Shewanella oneidensis MR-1 species (Flynn et al., 2010), or it can be produced from the reduction of acetate by a microbial mixed culture in MECs (Steinbusch et al., 2010). As the material and microbiological techniques advance, we expect that more valuable chemicals are going to be producible in the cathode of MXCs. Thus far, the rate of chemical production is still too low to justify the processes. The purity of the produced chemicals also needs to be raised to reduce excess energy and economic cost for product purification. The long-term stability of chemical production systems needs to be evaluated. Increasing the catalytic activity, selectivity, and durability of microbial catalysts, optimizing the system configuration, and better understanding the interactions between different parts of the system will be useful to solve the above problems, thus to promote the large-scale application of these microbial electrosynthesis processes.

\section{Conclusions}

MFCs hold great promise for realizing the sustainability of wastewater treatment. At present, the real-world large-scale application of this attractive technology is still in progress. Scientists and engineers from all over the world are making great efforts to develop large-scale MFCs and to settle the problems limiting the scaling up of MFCs, such as the low power output, high capital cost, low energy harvesting efficiency, and poor system stability. Studies regarding the integration of MFCs with other techniques to give high effluent quality or for recovering energy rich or highly valuable chemicals have just emerged, and challenges in the electricity/chemical production efficiency, wastewater treatment effectiveness, economic feasibility, and system stability need to be overcome for the practical application of these techniques. Joint efforts from experts in reactor design, material engineering, system optimization, and biological manipulation are required in the future to realize sustainable wastewater treatment by MFCs.

\section{References}

Aelterman, P., Rabaey, K., Pham, H.T., et al., 2006. Continuous electricity generation at high voltages and currents using stacked microbial fuel cells. Environmental Science \& Technology, 40(10):3388-3394. [doi:10.1021/ es0525511]

Ahmed, J.K.S., 2011. Effect of cathodic biofilm on the performance of air-cathode single chamber microbial fuel cells. Bulletin of the Korean Chemical Society, 32(10): 3726-3729. [doi:10.5012/bkcs.2011.32.10.3726]

Ahn, Y., Zhang, F., Logan, B.E., 2014. Air humidity and water pressure effects on the performance of air-cathode microbial fuel cell cathodes. Journal of Power Sources, 247:655-659. [doi:10.1016/j.jpowsour.2013.08.084]

An, J., Jeon, H., Lee, J., et al., 2011. Bifunctional silver nanoparticle cathode in microbial fuel cells for microbial growth inhibition with comparable oxygen reduction reaction activity. Environmental Science \& Technology, 45(12):5441-5446. [doi:10.1021/es2000326]

Aulenta, F., Tocca, L., Verdini, R., et al., 2011. Dechlorination of trichloroethene in a continuous-flow bioelectrochemical reactor: effect of cathode potential on rate, selectivity, and electron transfer mechanisms. Environmental Science \& Technology, 45(19):8444-8451. [doi:10.1021/ es202262y]

Bond, D.R., Lovley, D.R., 2003. Electricity production by geobacter sulfurreducens attached to electrodes. Applied and Environmental Microbiology, 69(3):1548-1555. [doi:10.1128/AEM.69.3.1548-1555.2003]

Bond, D.R., Lovley, D.R., 2005. Evidence for involvement of an electron shuttle in electricity generation by geothrix fermentans. Applied and Environmental Microbiology, 71(4):2186-2189. [doi:10.1128/AEM.71.4.2186-2189. 2005]

Borole, A.P., Reguera, G., Ringeisen, B., et al., 2011. Electroactive biofilms: current status and future research needs. Energy \& Environmental Science, 4(12):48134834. [doi:10.1039/c1ee02511b] 
Cai, T., Park, S.Y., Li, Y., 2013. Nutrient recovery from wastewater streams by microalgae: status and prospects. Renewable and Sustainable Energy Reviews, 19:360-369. [doi:10.1016/j.rser.2012.11.030]

Call, D., Logan, B.E., 2008. Hydrogen production in a single chamber microbial electrolysis cell lacking a membrane. Environmental Science \& Technology, 42(9):3401-3406. [doi:10.1021/es8001822]

Cao, X., Huang, X., Liang, P., et al., 2009. A new method for water desalination using microbial desalination cells. Environmental Science \& Technology, 43(18):7148-7152. [doi:10.1021/es901950j]

Cha, J., Choi, S., Yu, H., et al., 2010. Directly applicable microbial fuel cells in aeration tank for wastewater treatment. Bioelectrochemistry, 78(1):72-79. [doi:10. 1016/j.bioelechem.2009.07.009]

Chen, G.W., Choi, S.J., Lee, T.H., et al., 2008. Application of biocathode in microbial fuel cells: cell performance and microbial community. Applied Microbiology and Biotechnology, 79(3):379-388. [doi:10.1007/s00253-0081451-0]

Chen, X., Xia, X., Liang, P., et al., 2011. Stacked microbial desalination cells to enhance water desalination efficiency. Environmental Science \& Technology, 45(6): 2465-2470. [doi:10.1021/es103406m]

Cheng, S., Logan, B.E., 2011. Increasing power generation for scaling up single-chamber air cathode microbial fuel cells. Bioresource Technology, 102(6):4468-4473. [doi:10. 1016/j.biortech.2010.12.104]

Cheng, S., Liu, H., Logan, B.E., 2006. Power densities using different cathode catalysts (Pt and CoTMPP) and polymer binders (nafion and PTFE) in single chamber microbial fuel cells. Environmental Science \& Technology, 40(1): 364-369. [doi:10.1021/es0512071]

Cheng, S., Xing, D., Call, D.F., et al., 2009. Direct biological conversion of electrical current into methane by electromethanogenesis. Environmental Science \& Technology, 43(10):3953-3958. [doi:10.1021/es803531g]

Cheng, S., Liu, W., Guo, J., et al., 2014a. Effects of hydraulic pressure on the performance of single chamber aircathode microbial fuel cells. Biosensors and Bioelectronics, 56:264-270. [doi:10.1016/j.bios.2014.01.036]

Cheng, S., Ye, Y., Ding, W., et al., 2014b. Enhancing power generation of scale-up microbial fuel cells by optimizing the leading-out terminal of anode. Journal of Power Sources, 248:931-938. [doi:10.1016/j.jpowsour.2013.10. 014]

Chung, K., Fujiki, I., Okabe, S., 2011. Effect of formation of biofilms and chemical scale on the cathode electrode on the performance of a continuous two-chamber microbial fuel cell. Bioresource Technology, 102(1):355-360. [doi:10.1016/j.biortech.2010.04.091]

Clauwaert, P., Verstraete, W., 2009. Methanogenesis in membraneless microbial electrolysis cells. Applied Microbiology and Biotechnology, 82(5):829-836. [doi:10. 1007/s00253-008-1796-4]
Clauwaert, P., Aelterman, P., Pham, T., et al., 2008a. Minimizing losses in bio-electrochemical systems: the road to applications. Applied Microbiology and Biotechnology, 79(6):901-913. [doi:10.1007/s00253-008-1522-2]

Clauwaert, P., Tolêdo, R., van der Ha, R.C., et al., 2008 b. Combining biocatalyzed electrolysis with anaerobic digestion. Water Science \& Technology, 57(4):575-579. [doi:10.2166/wst.2008.084]

Clauwaert, P., Mulenga, S., Aelterman, P., et al., 2009. Litre-scale microbial fuel cells operated in a complete loop. Applied Microbiology and Biotechnology, 83(2): 241-247. [doi:10.1007/s00253-009-1876-0]

Cusick, R.D., Kiely, P.D., Logan, B.E., 2010. A monetary comparison of energy recovered from microbial fuel cells and microbial electrolysis cells fed winery or domestic wastewaters. International Journal of Hydrogen Energy, 35(17):8855-8861. [doi:10.1016/j.ijhydene.2010.06.077]

Dekker, A., Heijne, A.T., Saakes, M., et al., 2009. Analysis and improvement of a scaled-up and stacked microbial fuel cell. Environmental Science \& Technology, 43(23): 9038-9042. [doi:10.1021/es901939r]

Dewan, A., Donovan, C., Heo, D., et al., 2010. Evaluating the performance of microbial fuel cells powering electronic devices. Journal of Power Sources, 195(1):90-96. [doi:10.1016/j.jpowsour.2009.07.001]

Donovan, C., Dewan, A., Peng, H., et al., 2011. Power management system for a $2.5 \mathrm{~W}$ remote sensor powered by a sediment microbial fuel cell. Journal of Power Sources, 196(3):1171-1177. [doi:10.1016/j.jpowsour. 2010.08.099]

Du, Z., Li, H., Gu, T., 2007. A state of the art review on microbial fuel cells: A promising technology for wastewater treatment and bioenergy. Biotechnology Advances, 25(5): 464-482. [doi:10.1016/j.biotechadv.2007.05.004]

Durruty, I., Bonanni, P.S., González, J.F., et al., 2012. Evaluation of potato-processing wastewater treatment in a microbial fuel cell. Bioresource Technology, 105:81-87. [doi:10.1016/j.biortech.2011.11.095]

Fan, Y., Han, S.K., Liu, H., 2012. Improved performance of CEA microbial fuel cells with increased reactor size. Energy \& Environmental Science, 5(8):8273-8280. [doi:10.1039/c2ee21964f]

Feng, Y., Wang, X., Logan, B.E., et al., 2008. Brewery wastewater treatment using air-cathode microbial fuel cells. Applied Microbiology and Biotechnology, 78(5): 873-880. [doi:10.1007/s00253-008-1360-2]

Flynn, J.M., Ross, D.E., Hunt, K.A., et al., 2010. Enabling unbalanced fermentations by using engineered electrodeinterfaced bacteria. mBio, 1(5):00190-00110. [doi:10. 1128/mBio.00190-10]

Foley, J.M., Rozendal, R.A., Hertle, C.K., et al., 2010. Life cycle assessment of high-rate anaerobic treatment, microbial fuel cells, and microbial electrolysis cells. Environmental Science \& Technology, 44(9):3629-3637. [doi:10.1021/es100125h] 
Fornero, J.J., Rosenbaum, M., Angenent, L.T., 2010. Electric power generation from municipal, food, and animal wastewaters using microbial fuel cells. Electroanalysis, 22(7-8):832-843. [doi:10.1002/elan.200980011]

Freguia, S., Teh, E.H., Boon, N., et al., 2010. Microbial fuel cells operating on mixed fatty acids. Bioresource Technology, 101(4):1233-1238. [doi:10.1016/j.biortech. 2009.09.054]

Ge, Z., Ping, Q., He, Z., 2013. Hollow-fiber membrane bioelectrochemical reactor for domestic wastewater treatment. Journal of Chemical Technology \& Biotechnology, 88(8):1584-1590. [doi:10.1002/jctb.4009]

Hamelers, H.M., Ter Heijne, A., Sleutels, T.J.A., et al., 2010. New applications and performance of bioelectrochemical systems. Applied Microbiology and Biotechnology, 85(6) 1673-1685. [doi:10.1007/s00253-009-2357-1]

Harnisch, F., Schroder, U., 2010. From MFC to MXC: chemical and biological cathodes and their potential for microbial bioelectrochemical systems. Chemical Society Reviews, 39(11):4433-4448. [doi:10.1039/c003068f]

Harnisch, F., Sievers, G., Schröder, U., 2009. Tungsten carbide as electrocatalyst for the hydrogen evolution reaction in $\mathrm{pH}$ neutral electrolyte solutions. Applied Catalysis B: Environmental, 89(3-4):455-458. [doi:10. 1016/j.apcatb.2009.01.003]

He, Z., 2013. Microbial fuel cells: now let us talk about energy. Environmental Science \& Technology, 47(1):332-333. [doi:10.1021/es304937e]

Heidrich, E.S., Curtis, T.P., Dolfing, J., 2011. Determination of the internal chemical energy of wastewater. Environmental Science \& Technology, 45(2):827-832. [doi:10. 1021/es103058w]

Ieropoulos, I., Greenman, J., Melhuish, C., 2008. Microbial fuel cells based on carbon veil electrodes: stack configuration and scalability. International Journal of Energy Research, 32(13):1228-1240. [doi:10.1002/er.1419]

Jacobson, K.S., Drew, D.M., He, Z., 2011. Efficient salt removal in a continuously operated upflow microbial desalination cell with an air cathode. Bioresource Technology, 102(1):376-380. [doi:10.1016/j.biortech.2010.06. 030]

Kalathil, S., Lee, J., Cho, M.H., 2011. Granular activated carbon based microbial fuel cell for simultaneous decolorization of real dye wastewater and electricity generation. New Biotechnology, 29(1):32-37. [doi:10.1016/j.nbt. 2011.04.014]

Kim, D., An, J., Kim, B., et al., 2012. Scaling-up microbial fuel cells: configuration and potential drop phenomenon at series connection of unit cells in shared anolyte. ChemSusChem, 5(6):1086-1091. [doi:10.1002/cssc. 201100678]

Kim, Y., Hatzell, M.C., Hutchinson, A.J., et al., 2011. Capturing power at higher voltages from arrays of microbial fuel cells without voltage reversal. Energy \& Environmental Science, 4(11):4662-4667. [doi:10.1039/ c1ee02451e]
Larrosa-Guerrero, A., Scott, K., Head, I.M., et al., 2010. Effect of temperature on the performance of microbial fuel cells. Fuel, 89(12):3985-3994. [doi:10.1016/j.fuel.2010.06.025]

Ledezma, P., Greenman, J., Ieropoulos, I., 2013. MFC-cascade stacks maximise COD reduction and avoid voltage reversal under adverse conditions. Bioresource Technology, 134:158-165. [doi:10.1016/j.biortech.2013.01.119]

Lee, H.S., Rittmann, B.E., 2010. Characterization of energy losses in an upflow single-chamber microbial electrolysis cell. International Journal of Hydrogen Energy, 35(3): 920-927. [doi:10.1016/j.ijhydene.2009.11.040]

Lefebvre, O., Uzabiaga, A., Chang, I., et al., 2011. Microbial fuel cells for energy self-sufficient domestic wastewater treatment-a review and discussion from energetic consideration. Applied Microbiology and Biotechnology, 89(2):259-270. [doi:10.1007/s00253-010-2881-z]

Levine, A.D., Asano, T., 2004. Peer reviewed: recovering sustainable water from wastewater. Environmental Science \& Technology, 38(11):201A-208A. [doi:10.1021/ es040504n]

Li, C., Fang, H.H.P., 2007. Fermentative hydrogen production from wastewater and solid wastes by mixed cultures. Critical Reviews in Environmental Science and Technology, 37(1):1-39. [doi:10.1080/10643380600729071]

Li, W.W., Yu, H.Q., He, Z., 2014. Towards sustainable wastewater treatment by using microbial fuel cellscentered technologies. Energy \& Environmental Science, 7(3):911-924. [doi:10.1039/c3ee43106a]

Li, Z., Zhang, X., Lei, L., 2008. Electricity production during the treatment of real electroplating wastewater containing $\mathrm{Cr}^{6+}$ using microbial fuel cell. Process Biochemistry, 43(12):1352-1358. [doi:10.1016/j.procbio.2008.08.005]

Liu, H., Logan, B.E., 2004. Electricity generation using an air-cathode single chamber microbial fuel cell in the presence and absence of a proton exchange membrane. Environmental Science \& Technology, 38(14):4040-4046. [doi:10.1021/es0499344]

Liu, H., Cheng, S., Logan, B.E., 2005a. Power generation in fed-batch microbial fuel cells as a function of ionic strength, temperature, and reactor configuration. Environmental Science \& Technology, 39(14):5488-5493. [doi:10.1021/es050316c]

Liu, H., Grot, S., Logan, B.E., 2005b. Electrochemically assisted microbial production of hydrogen from acetate. Environmental Science \& Technology, 39(11):4317-4320. [doi:10.1021/es050244p]

Liu, H., Cheng, S., Huang, L., et al., 2008. Scale-up of membrane-free single-chamber microbial fuel cells. Journal of Power Sources, 179(1):274-279. [doi:10. 1016/j.jpowsour.2007.12.120]

Liu, L., Li, F.B., Feng, C.H., et al., 2009. Microbial fuel cell with an azo-dye-feeding cathode. Applied Microbiology and Biotechnology, 85(1):175-183. [doi:10.1007/ s00253-009-2147-9]

Logan, B.E., 2009. Exoelectrogenic bacteria that power microbial fuel cells. Nature Reviews Microbiology, 7(5): 375-381. [doi:10.1038/nrmicro2113] 
Logan, B.E., 2010. Scaling up microbial fuel cells and other bioelectrochemical systems. Applied Microbiology and Biotechnology, 85(6):1665-1671. [doi:10.1007/s00253009-2378-9]

Logan, B.E., Cheng, S., Watson, V., et al., 2007. Graphite fiber brush anodes for increased power production in aircathode microbial fuel cells. Environmental Science \& Technology, 41(9):3341-3346. [doi:10.1021/es062644y]

Lovley, D.R., 2011. Powering microbes with electricity: direct electron transfer from electrodes to microbes. Environmental Microbiology Reports, 3(1):27-35. [doi:10.1111/ j.1758-2229.2010.00211.x]

McCarty, P.L., Bae, J., Kim, J., 2011. Domestic wastewater treatment as a net energy producer - can this be achieved? Environmental Science \& Technology, 45(17):7100-7106. [doi:10.1021/es2014264]

Min, B., Logan, B.E., 2004. Continuous electricity generation from domestic wastewater and organic substrates in a flat plate microbial fuel cell. Environmental Science \& Technology, 38(21):5809-5814. [doi:10.1021/es0491026]

Min, B., Cheng, S., Logan, B.E., 2005a. Electricity generation using membrane and salt bridge microbial fuel cells. Water Research, 39(9):1675-1686. [doi:10.1016/j.watres. 2005.02.002]

Min, B., Kim, J., Oh, S., et al., 2005b. Electricity generation from swine wastewater using microbial fuel cells. Water Research, 39(20):4961-4968. [doi:10.1016/j.watres.2005. 09.039]

Mu, Y., Rabaey, K., Rozendal, R.A., et al., 2009. Decolorization of azo dyes in bioelectrochemical systems. Environmental Science \& Technology, 43(13):5137-5143. [doi:10.1021/es900057f]

Muga, H.E., Mihelcic, J.R., 2008. Sustainability of wastewater treatment technologies. Journal of Environmental Management, 88(3):437-447. [doi:10.1016/j.jenvman.2007. 03.008]

Nevin, K.P., Woodard, T.L., Franks, A.E., et al., 2010. Microbial electrosynthesis: feeding microbes electricity to convert carbon dioxide and water to multicarbon extracellular organic compounds. mBio, 1(2):103-110. [doi:10.1128/mBio.00103-10]

Nowak, O.K.S., Fimml, C., 2011. Examples of energy self-sufficient municipal nutrient removal plants. Water Science \& Technology, 64(1):1-6. [doi:10.2166/wst.2011. 625]

Oh, S.T., Kim, J.R., Premier, G.C., et al., 2010. Sustainable wastewater treatment: how might microbial fuel cells contribute. Biotechnology Advances, 28(6):871-881. [doi:10.1016/j.biotechadv.2010.07.008]

Pant, D., van Bogaert, G., Diels, L., et al., 2010. A review of the substrates used in microbial fuel cells (MFCs) for sustainable energy production. Bioresource Technology, 101(6):1533-1543. [doi:10.1016/j.biortech.2009.10.017]

Pant, D., Singh, A., van Bogaert, G., et al., 2012. Bioelectrochemical systems (BES) for sustainable energy production and product recovery from organic wastes and industrial wastewaters. RSC Advances, 2(4):1248-1263. [doi:10.1039/c1ra00839k]

Park, J.D., Ren, Z., 2012a. High efficiency energy harvesting from microbial fuel cells using a synchronous boost converter. Journal of Power Sources, 208(0):322-327. [doi:10.1016/j.jpowsour.2012.02.035]

Park, J.D., Ren, Z., 2012b. Hysteresis controller based maximum power point tracking energy harvesting system for microbial fuel cells. Journal of Power Sources, 205: 151-156. [doi:10.1016/j.jpowsour.2012.01.053]

Pham, T.H., Rabaey, K., Aelterman, P., et al., 2006. Microbial fuel cells in relation to conventional anaerobic digestion technology. Engineering in Life Sciences, 6(3):285-292. [doi:10.1002/elsc.200620121]

Qiao, Y., Li, C.M., Bao, S.J., et al., 2008. Direct electrochemistry and electrocatalytic mechanism of evolved Escherichia coli cells in microbial fuel cells. Chemical Communications, 11:1290-1292. [doi:10.1039/b7199 $55 \mathrm{~d}]$

Rabaey, K., Verstraete, W., 2005. Microbial fuel cells: novel biotechnology for energy generation. Trends in Biotechnology, 23(6):291-298. [doi:10.1016/j.tibtech.2005. 04.008]

Rabaey, K., Rozendal, R.A., 2010. Microbial electrosynthesis -revisiting the electrical route for microbial production. Nature Reviews Microbiology, 8(10):706-716. [doi:10. 1038/nrmicro2422]

Rabaey, K., van de Sompel, K., Maignien, L., et al., 2006. Microbial fuel cells for sulfide removal. Environmental Science \& Technology, 40(17):5218-5224. [doi:10.1021/ es060382u]

Rabaey, K., Bützer, S., Brown, S., et al., 2010. High current generation coupled to caustic production using a lamellar bioelectrochemical system. Environmental Science \& Technology, 44(11):4315-4321. [doi:10.1021/es9037963]

Ringeisen, B.R., Henderson, E., Wu, P.K., et al., 2006. High power density from a miniature microbial fuel cell using Shewanella oneidensis DSP10. Environmental Science \& Technology, 40(8):2629-2634. [doi:10.1021/es052254w]

Rismani-Yazdi, H., Carver, S.M., Christy, A.D., et al., 2008. Cathodic limitations in microbial fuel cells: an overview. Journal of Power Sources, 180(2):683-694. [doi:10. 1016/j.jpowsour.2008.02.074]

Rittmann, B.E., 2008. Opportunities for renewable bioenergy using microorganisms. Biotechnology and Bioengineering, 100(2):203-212. [doi:10.1002/bit.21875]

Rozendal, R.A., Hamelers, H.V.M., Euverink, G.J.W., et al., 2006. Principle and perspectives of hydrogen production through biocatalyzed electrolysis. International Journal of Hydrogen Energy, 31(12):1632-1640. [doi:10.1016/j. ijhydene.2005.12.006]

Rozendal, R.A., Hamelers, H.V.M., Molenkamp, R.J., et al., 2007. Performance of single chamber biocatalyzed electrolysis with different types of ion exchange membranes. Water Research, 41(9):1984-1994. [doi:10.1016/j.watres. 2007.01.019] 
Rozendal, R.A., Hamelers, H.V.M., Rabaey, K., et al., 2008a. Towards practical implementation of bioelectrochemical wastewater treatment. Trends in Biotechnology, 26(8): 450-459. [doi:10.1016/j.tibtech.2008.04.008]

Rozendal, R.A., Jeremiasse, A.W., Hamelers, H.V.M., et al., 2008b. Hydrogen production with a microbial biocathode. Environmental Science \& Technology, 42(2):629-634. [doi:10.1021/es071720+]

Rozendal, R.A., Leone, E., Keller, J., et al., 2009. Efficient hydrogen peroxide generation from organic matter in a bioelectrochemical system. Electrochemistry Communications, 11(9):1752-1755. [doi:10.1016/j.elecom.2009. 07.008]

Santoro, C., Lei, Y., Li, B., et al., 2012. Power generation from wastewater using single chamber microbial fuel cells (MFCs) with platinum-free cathodes and pre-colonized anodes. Biochemical Engineering Journal, 62:8-16. [doi:10.1016/j.bej.2011.12.006]

Santoro, C., Stadlhofer, A., Hacker, V., et al., 2013. Activated carbon nanofibers (ACNF) as cathode for single chamber microbial fuel cells (SCMFCs). Journal of Power Sources, 243:499-507. [doi:10.1016/j.jpowsour.2013.06. 061]

Schmidt, T.J., Paulus, U.A., Gasteiger, H.A., et al., 2001. The oxygen reduction reaction on a $\mathrm{Pt} /$ carbon fuel cell catalyst in the presence of chloride anions. Journal of Electroanalytical Chemistry, 508(1-2):41-47. [doi:10.1016/S00220728(01)00499-5]

Selembo, P.A., Merrill, M.D., Logan, B.E., 2009. The use of stainless steel and nickel alloys as low-cost cathodes in microbial electrolysis cells. Journal of Power Sources, 190(2):271-278. [doi:10.1016/j.jpowsour.2008.12.144]

Sharma, Y., Li, B., 2010. Optimizing energy harvest in wastewater treatment by combining anaerobic hydrogen producing biofermentor (HPB) and microbial fuel cell (MFC). International Journal of Hydrogen Energy, 35(8): 3789-3797. [doi:10.1016/j.ijhydene.2010.01.042]

Steinbusch, K.J.J., Hamelers, H.V.M., Schaap, J.D., et al., 2010. Bioelectrochemical ethanol production through mediated acetate reduction by mixed cultures. Environmental Science \& Technology, 44(1):513-517. [doi:10. 1021/es902371e]

Tartakovsky, B., Manuel, M.F., Wang, H., et al., 2009. High rate membrane-less microbial electrolysis cell for continuous hydrogen production. International Journal of Hydrogen Energy, 34(2):672-677. [doi:10.1016/j. ijhydene.2008.11.003]

Timmers, R., Strik, D.B.T.B., Hamelers, H.M., et al., 2010. Long-term performance of a plant microbial fuel cell with Spartina anglica. Applied Microbiology and Biotechnology, 86(3):973-981. [doi:10.1007/s00253-0102440-7]

Walker, A.L., Walker, C.W.Jr., 2006. Biological fuel cell and an application as a reserve power source. Journal of Power Sources, 160(1):123-129. [doi:10.1016/j.jpowsour.2006. 01.077]
Wang, A., Sun, D., Cao, G., et al., 2011. Integrated hydrogen production process from cellulose by combining dark fermentation, microbial fuel cells, and a microbial electrolysis cell. Bioresource Technology, 102(5):41374143. [doi:10.1016/j.biortech.2010.10.137]

Wang, B., Han, J.I., 2009. A single chamber stackable microbial fuel cell with air cathode. Biotechnology Letters, 31(3):387-393. [doi:10.1007/s10529-008-9877-0]

Wang, Y.K., Sheng, G.P., Shi, B.J., et al., 2013. A novel electrochemical membrane bioreactor as a potential net energy producer for sustainable wastewater treatment. Scientific Reports, 3:1864-1870. [doi:10.1038/srep 01864]

Watson, V.J., Saito, T., Hickner, M.A., et al., 2011. Polymer coatings as separator layers for microbial fuel cell cathodes. Journal of Power Sources, 196(6):3009-3014. [doi:10.1016/j.jpowsour.2010.11.105]

Watson, V.J., Nieto Delgado, C., Logan, B.E., 2013. Influence of chemical and physical properties of activated carbon powders on oxygen reduction and microbial fuel cell performance. Environmental Science \& Technology, 47(12):6704-6710. [doi:10.1021/es401722j]

Xing, D., Zuo, Y., Cheng, S., et al., 2008. Electricity generation by rhodopseudomonas palustris DX-1. Environmental Science \& Technology, 42(11):4146-4151. [doi:10.1021/es800312v]

Xu, J., Sheng, G.P., Luo, H.W., et al., 2012. Fouling of proton exchange membrane (PEM) deteriorates the performance of microbial fuel cell. Water Research, 46(6):1817-1824. [doi:10.1016/j.watres.2011.12.060]

Xu, Y., Jiang, Y., Chen, Y., et al., 2014. Hydrogen production and wastewater treatment in a microbial electrolysis cell with a biocathode. Water Environment Research, 86(7):649-653. [doi:10.2175/106143014X13975035525500]

Yan, H., Saito, T., Regan, J.M., 2012. Nitrogen removal in a single-chamber microbial fuel cell with nitrifying biofilm enriched at the air cathode. Water Research, 46(7): 2215-2224. [doi:10.1016/j.watres.2012.01.050]

Yang, S., Jia, B., Liu, H., 2009. Effects of the Pt loading side and cathode-biofilm on the performance of a membrane-less and single-chamber microbial fuel cell. Bioresource Technology, 100(3):1197-1202. [doi:10. 1016/j.biortech.2008.08.005]

You, S.J., Zhao, Q.L., Jiang, J.Q., et al., 2006a. Sustainable approach for leachate treatment: electricity generation in microbial fuel cell. Journal of Environmental Science and Health, Part A, 41(12):2721-2734. [doi:10.1080/ 10934520600966284]

You, S.J., Zhao, Q.L., Jiang, J.Q., et al., 2006b. Treatment of domestic wastewater with simultaneous electricity generation in microbial fuel cell under continuous operation. Chemical and Biochemical Engineering Quarterly, 20(4): 407-412.

Yu, J., Seon, J., Park, Y., et al., 2012. Electricity generation and microbial community in a submerged-exchangeable microbial fuel cell system for low-strength domestic 
wastewater treatment. Bioresource Technology, 117: 172-179. [doi:10.1016/j.biortech.2012.04.078]

Yuan, Y., Zhou, S., Tang, J., 2013. In situ investigation of cathode and local biofilm microenvironments reveals important roles of $\mathrm{OH}^{-}$and oxygen transport in microbial fuel cells. Environmental Science \& Technology, 47(9): 4911-4917. [doi:10.1021/es400045s]

Zhang, B., Zhao, H., Shi, C., et al., 2009a. Simultaneous removal of sulfide and organics with vanadium $(\mathrm{V})$ reduction in microbial fuel cells. Journal of Chemical Technology \& Biotechnology, 84(12):1780-1786. [doi:10. $1002 /$ jctb.2244]

Zhang, B., Zhao, H., Zhou, S., et al., 2009b. A novel UASB-MFC-BAF integrated system for high strength molasses wastewater treatment and bioelectricity generation. Bioresource Technology, 100(23):5687-5693. [doi:10.1016/j.biortech.2009.06.045]

Zhang, F., He, Z., 2012. Simultaneous nitrification and denitrification with electricity generation in dual-cathode microbial fuel cells. Journal of Chemical Technology \& Biotechnology, 87(1):153-159. [doi:10.1002/jctb.2700]

Zhang, F., Jacobson, K.S., Torres, P., et al., 2010. Effects of anolyte recirculation rates and catholytes on electricity generation in a litre-scale upflow microbial fuel cell. Energy \& Environmental Science, 3(9):1347-1352. [doi:10.1039/c001201g]

Zhang, F., Pant, D., Logan, B.E., 2011a. Long-term performance of activated carbon air cathodes with different diffusion layer porosities in microbial fuel cells. Biosensors and Bioelectronics, 30(1):49-55. [doi:10.1016/ j.bios.2011.08.025]

Zhang, F., Tian, L., He, Z., 2011b. Powering a wireless temperature sensor using sediment microbial fuel cells with vertical arrangement of electrodes. Journal of Power Sources, 196(22):9568-9573. [doi:10.1016/j.jpowsour. 2011.07.037]

Zhang, F., Ge, Z., Grimaud, J., et al., 2013a. In situ investigation of tubular microbial fuel cells deployed in an aeration tank at a municipal wastewater treatment plant. Bioresource Technology, 136:316-321. [doi:10. 1016/j.biortech.2013.02.107]

Zhang, F., Ge, Z., Grimaud, J., et al., 2013b. Long-term performance of liter-scale microbial fuel cells treating primary effluent installed in a municipal wastewater treatment facility. Environmental Science \& Technology, 47(9):4941-4948. [doi:10.1021/es400631r]

Zhang, X., Cheng, S., Wang, X., et al., 2009. Separator characteristics for increasing performance of microbial fuel cells. Environmental Science \& Technology, 43(21): 8456-8461. [doi:10.1021/es901631p]

Zhang, X., Cheng, S., Huang, X., et al., 2010. Improved performance of single-chamber microbial fuel cells through control of membrane deformation. Biosensors and Bioelectronics, 25(7):1825-1828. [doi:10.1016/j.bios.2009. 11.018]
Zhang, Y., Angelidaki, I., 2012. Bioelectrode-based approach for enhancing nitrate and nitrite removal and electricity generation from eutrophic lakes. Water Research, 46(19): 6445-6453. [doi:10.1016/j.watres.2012.09.022]

Zhang, Y., Noori, J.S., Angelidaki, I., 2011. Simultaneous organic carbon, nutrients removal and energy production in a photomicrobial fuel cell (PFC). Energy \& Environmental Science, 4(10):4340-4346. [doi:10.1039/ c1ee02089g]

Zhao, F., Harnisch, F., Schroder, U., et al., 2006. Challenges and constraints of using oxygen cathodes in microbial fuel cells. Environmental Science \& Technology, 40(17): 5193-5199. [doi:10.1021/es060332p]

Zhao, F., Rahunen, N., Varcoe, J.R., et al., 2009. Factors affecting the performance of microbial fuel cells for sulfur pollutants removal. Biosensors and Bioelectronics, 24(7):1931-1936. [doi:10.1016/j.bios.2008.09.030]

Zhou, M., Chi, M., Luo, J., et al., 2011. An overview of electrode materials in microbial fuel cells. Journal of Power Sources, 196(10):4427-4435. [doi:10.1016/j. jpowsour.2011.01.012]

Zhuang, L., Yuan, Y., Wang, Y., et al., 2012. Long-term evaluation of a 10-liter serpentine-type microbial fuel cell stack treating brewery wastewater. Bioresource Technology, 123:406-412. [doi:10.1016/j.biortech.2012.07. 038]

Dr. Shao-an CHENG

\section{Introducing editorial board member:}

Dr. Shao-an CHENG is a new editorial member of Journal of Zhejiang University-SCIENCE A (Applied Physics $\&$ Engineering) in 2014. He received his $\mathrm{BS}$ and $\mathrm{PhD}$ degrees both in material science and engineering from Zhejiang University, Hangzhou, China, in 1983 and 1995, respectively. From 1995 to 1997, he was a Postdoctoral Fellow at Zhejiang University. From 1997 to 1998, he was with the Department of Chemistry, Zhejiang University, where he became an Associate Professor in 1998. From 1998 to 2001, Dr. CHENG was a visiting professor at the University of Basque Country, San Sebastian, Spain. From 2001 to 2003, he was a postdoctoral research fellow at the University of Hong Kong, Hong Kong, China. From 2004 to 2008, he was a senior research associate 
at the Department of Civil and Environment Engineering of Pennsylvania State University, State College, USA. He moved to Department of Energy Engineering of Zhejiang University in 2008 as a Qiushi Scholar, and was awarded as Chang Jiang Scholar in the same year.

Dr. CHENG's current research interests include the microbial-photo-electrochemistry energy conversion system, energy recovery from waste water through bioelectrochemical system (BES). He is the author or coauthor of more than 150 refereed journal papers, among which about 100 are published in international journals, with citation of over 1500 . He has also coauthored two book chapters in English. Dr. CHENG was named amongst Thomson Reuters Highly Cited Researchers in the field of ENVIRONMENT/ECOLOGY in 2014.

\section{中文栍要:}

本文题目: 从废水中回收能量的微生物燃料电池技术: 走向实际应用的机遇和挑战

Microbial fuel cells for energy production from wastewaters: the way toward practical application

本文概要: 废水中蕴含着大量能量, 如何高效地回收利用这些能量对于满足世界能源需求, 降低废水处 理成本, 提高污水处理的可持续性具有重要意义。微生物燃料电池（MFC）是近年来发展起 来的一种从废水的有机污染物中提取能量的新型生物技术，有望实现废水处理的可持续性发 展。然而, 目前 MFC 技术离实际应用还有很长的距离。 MFC 系统的扩大化问题是阻碍该技 术实际应用的关键。本文详细讨论了 $\mathrm{MFC}$ 扩大化过程中的主要问题和挑战, 并提出了未来 的发展方向。MFC 与其他技术结合可以实现较高的出水水质或获得高商业价值的化学品, 然 而该方面的研究才刚刚起步, 要实现其实际应用还需要解决许多问题, 包括如何提高生产效 率, 提高经济可行性, 提升系统的稳定性和可靠性等。

关键词组: 微生物燃料电池; 废水处理; 可持续发展; 扩大化; 合成化学品 